\title{
ON THE SYSTEMATIC POSITION OF THE WESTERN HAMSTER, CRICETUS CRICETUS CANESCENS NEHRING (MAMMALIA: RODENTIA) \\ by
}

A. M. HUSSON

(Rijksmuseum van Natuurlijke Historie, Leiden)

\section{INTRODUCTION}

The systematic position of the western hamster, Cricetus cricetus canescens, has been a subject of discussion and criticism ever since NeHring (1899, pp. 1-2) described the hamster occurring in Belgium west of the Meuse as a separate variety. The present paper is a new effort to throw more light on the interesting question concerning the systematic characters by which the western hamster can be distinguished from the typical form described from central Germany. For a better understanding of the present study a brief survey of the main points in the historical development of this problem follows here.

According to Nehring the main characters in which his new variety, Cricetus vulgaris var. canescens, differed from the typical form, were: (1) the dark mouse-greyish colour of the dorsal surface, (2) the less intensive black colour of the ventral surface, (3) the smaller size, and (4) the presumably larger ears. It is to be noted, however, that NeHring based his description merely on two stuffed skins from the neighbourhood of Fexhe-Slins, Belgium, which he compared with specimens from Saxony and Brandenburg.

Miller (1912, p. 603) came to the following conclusion: "The status of this race is not satisfactory. The Belgian specimens which I have seen show none of the peculiarities in colour described by Nehring, but agree perfectly in this respect with those from central Germany. The small size of their skulls, however, is too pronounced a character to permit the name canescens to be placed in the synonymy of true cricetus". From the table of cranial measurements of Cricetus cricetus (l.c., p. 604) it appears that the condylobasal lengths of his two Belgian canescens specimens are 44.0 and $45.2 \mathrm{~mm}$, while this measurement for his eleven specimens of true cricetus varies between 47.0 and $51.4 \mathrm{~mm}$. For this reason Miller considered a specimen from Brunswick with a con- dylobasal length of $45.6 \mathrm{~mm}$ to belong to canescens. Dupond (1932, pp. 40-41) examined a specimen from Beauvechain near Louvain, of which he supposed, basing himself on the total length of the animal, that "le crâne devait certainement atteindre une longueur condylobasale d'au moins $50 \mathrm{~mm}$ ", and concluded: "Il semble donc en résulter que les caractères du crâne, pour canescens, invoqués par Miller, ne sont pas non plus ni constant ni généraux!"

Novikov (1935) extensively discussed the systematic peculiarities of the subspecies of Cricetus cricetus. A free English translation of his remarks concerning the Belgian hamster (l.c., p. 302) runs as follows. "Lack of material does not allow me to decide with certainty whether or not differences do exist between the Belgian and the German hamster, but since Professor Nehring based his description of the Belgian hamster on a single specimen only 1 ), we must consider his "new subspecies" with a great deal of reserve. Nehring compared this Belgian specimen with two typical German hamsters (one from Saxony and one from Brandenburg). According to Professor Nehring the characters in which the Belgian hamster differs from the German form are its dark mousegreyish colour and its larger size 2). This colour, however, is common in young hamsters. In my opinion, therefore, the specimen on which Professor Nehring based his "new subspecies", is a young individual, which, as pointed out above, can be distinguished from adult specimens by its dull greyish colour. Furthermore nothing is known about the way in which the specimen has been preserved, either in spirit or in formalin. ..... Professor Nehring's de-

1) Novikov is mistaken here, since Nehring actually based his description on "zwei ausgestopfte Hamster aus der Gegend von Fexhe-Slins in Belgien".

2) Presumably this is a slip of the pen by Novikov since smaller size instead of larger is noted by NeHRING. 
scription is far from satisfactory and cannot be used to distinguish a separate subspecies".

After having examined all the specimens of Cricetus cricetus from Belgium present in the Brussels Museum, FrechKop (1936, pp. 125-126) came to the conclusion that Novikov's view is quite correct, and remarked: "Ainsi la sous-espèce canescens paraît actuellement parfaitement infirmée".

In the same year, however, WEPNER (1936) pointed out some other characters of the western hamster, which make the subspecific status of canescens unquestionable, since this author noted (l.c., p. 256): "Bauch- und Beinzeichnung weichen von einander ab. Der weisse Fleck unterhalb der Schnauze ist bei canescens weiter ausgezogen und läuft auf dem Hals spitz aus. Bei cricetus ist Brust und Bauch durchgehend schwarz gefärbt, bei canescens nicht. Hier befindet sich vielmehr auf der Brust zwischen den Vorderbeinen ein weisser Fleck; .... Die Hinterbeine haben bei canescens die gleiche Zeichnung wie bei cricetus. Die Vorderbeine dagegen weichen ab; sie haben bei cricetus nur weisse Füsse, bei canescens auch weisse Manchetten. Die weisse Zeichnung erstreckt sich also bei cricetus nur wenig über das Handgelenk, bei canescens aber fast über den ganzen Unterarm und ist hier an der Aussenseite des Beines breiter als an der Innenseite. - Auch die Schädelmaasse ergeben einige Unterschiede: canescens hat sowohl absolut wie relativ grössere Occipitalbreite und grössere Interorbitalbreite. .... Alle bekannte Stücke aus dem Gebiet links des Rheines gehören zu canescens, alle aus dem deutschen Gebiet rechts des Rheines zu cricetus."

WePNer (1936) was not the first to notice the presence of a white spot or stripe on the breast of the hamster. To my knowledge Brants (1827, p. 158) was the first to refer to this character, in his description of the hamster mentioning "een wit vlekjen op de borst" (a white spot on the breast). Unfortunately Brants did not specify the localities of his material. DEBY (1848, vol. 2, p. 98) noted with respect to the Belgian hamster: "la gorge et la poitrine présentent chacune une tache blanche". Honvath (1881, p. 218. footnote 2) made the following remark concerning the hamster from near Strasbourg: "Was die Hamster betrifft, so wurde beobachtet, dass alle Thiere (5 Stück), welche unweit von Strassburg in Enzheim gefangen wurden, in ihrem schwarzen Brustflecken (in der Mitte desselben) eine weisse Linie zeigten, wogegen bei sämmtlichen Hamstern (20 Stück) welche in Sachsen gefangen wurden, dieser Streifen fehlte". Didien \& Rode (1935, p. 249) in their description of the French hamster stated: "Tache trans- versale blanche sous le sternum". EYxman (1937, p. 48), who considered the hamster occurring in the southern part of the Dutch province of Limburg to belong to Cricetus cricetus canescens, noted: "Onderdeelen geheel zwart, behalve witte streep tusschen de voorpooten. Soms een witte vlek tusschen de voorpooten". (Under parts quite black with the exception of a white stripe between the fore legs. Sometimes a white spot between the fore legs). It must be noted, however, that many other authors dealing with the hamster occurring west of the Rhine do not mention this character in their description. This of course need not mean that in the hamsters examined by them the white spot on the breast actually was not present, but it may mean only that it was overlooked by them or considered to be of little importance.

In view of the fact that this white spot was observed in specimens of the western hamster as early as 1848 and regularly afterwards, the question now arises what colour patterns are observed in the central part of the area of distribution of the hamster. Sulzer (1774) published a most important and critical study on Cricetus cricetus, in which on page 36 he stated: “... und überhaupt, welches ich beyläufig anmerke, ist es zu verwundern, wie beständig, und wie wenigen Abweichungen die Farben des Hamsters unterworfen sind", and on page 49: "Sehr selten findet man bey den kleinsten Fleckgen einige Verschiedenheit". Also PETzSCH (1933, p. 222) remarked: "Obgleich mir in jedem Jahre nach der Ernte Hamster gebracht und gezeigt wurden bzw. ich sie selbst ausgrub, fand ich doch nie ein Exemplar darunter, das irgendwie in der Anordnung der Farben vom normalen Allgemeinaussehen abgewichen wäre". However, PETzSCH (1936, pp. 44-45) reports having observed the white spot under discussion in some specimens in his material, at the same time noting that Honvath's 1881 paper had drawn his attention to this character. Thereupon he carried out breeding experiments which led him to the following conclusions: "Der weisse Brustfleck beim normalbunten Hamster, der als Merkmal der westeuropäischen Unterart des Hamsters (Cricetus cricetus canescens Nehring) beschrieben wurde ist kein Merkmal dieser Unterart. Er tritt auch bei Hamstern aus der Dresdner Umgebung und aus Thüringen auf. Es hat einigen Anschein, als würde er dominant vererbt". It is hard to believe that no German mammalogists before 1936 should have noted a white spot on the breast of the specimens examined, if this spot was present at all.

Finally I should remark that though Petzsch (1949, p. 4; 1950, p. 16) does not consider the white 
spot on the breast of the hamster to be a character of subspecific value, he does not expressly deny the subspecific status of the western form. Also ELLERMaN \& MoRrison-ScotT (1951, pp. 628-629) maintain this status of canescens, though "provisionally until more material comes to hand".

In order to explain the above-mentioned data the following hypothesis seems attractive: (a) quite some time ago a mutation or a series of mutations has occurred in a population living west of the Rhine or of the Meuse; this mutation has produced the white spot in the previously black ventral surface together with the other external characters mentioned by WEPNER $(1936$, p. 256) for the western hamster; (b) the gene corresponding to this mutation is dominant (this part of the hypothesis being plausible because all available data tend to show that at present all individuals occurring in Belgium and the Netherlands show the white spots described above); (c) only during the last few decades the mutant has begun to spread eastwards.

This hypothesis would explain the curious fact that in the literature published before 1936 no mention is made of hamsters living in central Germany which show the above-described white pattern, whereas the present situation is completely different: in a letter dated June 12, 1949, Dr. Petzsch informed me that "In Reick bei Dresden haben etwa $30 \%$ aller dortigen Hamster dieses Merkmal". In view of parts (a) and (b) of the hypothesis one would be led to expect an increasing number of white-spotted western type hamsters in central Germany. Hence it would be interesting indeed to keep track of the development of this character in central Germany. Although the hypothesis under discussion connects known facts and suggests lines of further study, it is not quite satisfactory because of the great variability of the character in question: in some individuals the white "spot" on the black ventral surface consists of a few white hairs only, in others there are large irregular patches, which may become so large as to give the animals the appearance of being partially albinistic. It might be interesting to compare this situation with a similar one in domestic animals (see Allen, 1914; Petzsch, 1940 a).

So far for the pattern of white spots on the ventral surface of the hamsters of western and central Europe. The hamsters in central Germany are influenced by yet another phenomenon: in Russia a melanistic phenotype of the hamster has been known for a long time. Now, among all western hamsters I examined I found not a single melanistic specimen.
In central Germany, however, melanistic specimens are much more common, and according to PETZSCH (1956, p. 151) this melanistic character seems to be dominant over the typical form: "Abschliessend können wir feststellen: Wir haben am melanistischen Hamster wohl tatsächlich ein Beispiel der Entstehung und progressiven Ausbreitung seiner neuen Erscheinungsform bzw. Farbrasse aus einer andersfarbigen Stammform heraus vor uns, welche letztere sie nun, kraft ihrer Dominanz bei der Vererbung, auf unblutigem Wege phänotypisch nahezu zum Verschwinden bringt und ersetzt". Hence in central Germany two mutants and the typical form seem to collide with each other, while both the western white-spotted mutant and the eastern melanistic mutant apparently are dominant over the typical form. As far as I know, no breeding experiments were conducted so far between the western hamster and the melanistic hamster. Therefore, an interesting question is still open: is the melanistic character dominant over the white-spotted one or vice versa? In this respect it is worth noticing that in the collection of the British Museum there is a melanistic specimen (B.M. 44.10. 12.1 , O) which is entirely black but for a white spot on the breast, this spot being $10 \mathrm{~mm}$ long and $8 \mathrm{~mm}$ wide. The specimen came "from Europe", but the exact locality is unknown. In the same collection (B.M. 58.9.12.6) there is also a melanistic specimen with a distinct white area on the throat pointing backwards, and with white cuffs on the fore legs; unfortunately no data are known as to the locality or date of this specimen.

For the general distribution of Cricetus cricetus and its subspecies I refer to Petzsch (1950, p. 17) and to Ellerman \& Morrison-Scott (1951, pp. 628-629), for a more detailed distribution in Germany to NeHRING (1893, map iii) and WerTH (1934, map 5), and for Belgium and the Netherlands to Dupond (1932, p. 14) and Husson (1949 a, p. 14).

The present investigation is based on the material of Cricetus cricetus (Linnaeus) in the Leiden Museum, and on extensive material from other institutions. I am much indebted to Mr. P. J. vaN DER FEeN (Zoölogisch Museum, Amsterdam), Dr. L. Forcart (Naturhistorisches Museum, Basel), Dr. S. FrechKop (Institut Royal des Sciences naturelles de Belgique, Brussels), Professor Dr. R. Mertens (Senckenbergische Naturforschende Gesellschaft, Frankfurt am Main), Dr. F. Carpentier (Institut zoologique Ed. van Beneden, Liége), Dr. T. C. S. Morrison-ScotT (British Museum, Natural History, London), Dr. Tr. HaLtenorth (Zoologische Staatssammlung, Mün- 
chen), and Dr. F. Gourn (Musée zoologique de l'Université et de la Ville, Strasbourg), for the loan of specimens from the collections at that time under their charge. It is my pleasant duty to express here my sincere gratitude to Dr. A. KLEINSCHMIDT (Naturhistorisches Museum, Braunschweig) for a fine series of skins and skulls of the hamster from near Brunswick, which now are placed in the Leiden Museum.

In the present paper the following abbreviations have been used: A. (Zoölogisch Museum, Amster- dam); Ba. (Naturhistorisches Museum, Basel); B.M. (British Museum, Natural History, London); Br. (Institut Royal des Sciences naturelles de Belgique, Brussels); dam. (damaged); F. (Senckenbergische Naturforschende Gesellschaft, Frankfurt am Main); L. (Rijksmuseum van Natuurlijke Historie, Leiden); Li. (Institut zoologique Ed. van Beneden, Liège); Mu. (Zoologische Staatssammlung, München); sn. (skin); sl. (skull); St. (Musée zoologique de l'Université et de la Ville, Strasbourg).

\section{MATERIAL EXAMINED}

\section{ZOOLOGISCH MUSEUM, AMSTERDAM}

The Netherlands, southern part of the province of Limburg.

1. Gulpen: Sep. 2, 1941, + , sn., dam. sl. (no. 2062).

2. Bocholtz: Aug. 19, 1940, $\&$, sn., dam. sl. (no. 2063); Oct. 15, 1940, ô, sn. (no. 2066).

3. Valkenburg: Aug. 1926, $3 \delta \hat{\delta}$, sn., sl. (no. $2067 \mathrm{x}, \mathrm{y}$, and z) - $6 \hat{\delta} \hat{\delta}$, sl. (no. $2068 \mathrm{a}, \mathrm{h}, \mathrm{j}, \mathrm{k}, \mathrm{n}$, and v) 8 Q , sl. (no. 2068 c. e. f, g, i, m, o, and p) -2 sl. (nos. 2071, 58/38, and 2071, 59/38); June 3, 1938, Q, sn., dam. sl. (no. 2064) - , sl. (no. 2071, 60/38); Aug. 28, 1940, sn., dam. sl. (no. 2077); Oct., 1940, sl. (no. 2070); Sep. 2, 1949, ㅇ, dam. sl.

4. Houthem, W. of Valkenburg: Sep. 12, 1925, ô, sn., dam. sl. (no. 2065).

5. South Limburg, without exact locality: June 12, 1941, juv. $q$, sn. (no. 2082) - juv., sn. (no. Artis, A.).

\section{NATURHISTORISCHES MUSEUM, BASLE}

Germany.

1. Thüringia: 1932, juv. $\hat{\delta}$, sn., sl. (nos. 4419 and 8348).

2. Leipzig: 1924, $\delta$ and $\&$, sn. (nos. 3355 ; 3356).

Poland.

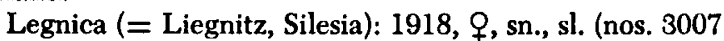
and 5875).

Czechoslovakia.

Bohemia: 1880, sl. (no. 2115).

Romania.

Near Bucharest: 1934, §ิ, sn., dam. sl. (nos. 4671 and 8653).

Russia.

Volga River: 1862, sn. (no. 715).

Locality unknown: 5 sl. (nos. 11, 180, 1579, 3048, and 4938).

\section{INSTITUT ROYAL DES SCIENCES NATURELLES DE BELGIQUE, BRUSSELS}

Belgium.

1. Fouron-le-Comte, N.E. of Visé, east of the Meuse: Aug. 31, 1931, ơ, sn., dam. sl. (no. $480 \zeta$ ).

2. Lathuy, S.W. of Tirlemont: Jan. 3, 1931, juv. $\hat{\delta}$, sn., sl. (no. 482); March 19, 1931, ᄋ, sn., dam. sl. (no. $482 \beta$ ).
3. Heverlée, Louvain: Aug. 5, 1939, sl. (no. 1623 ס); Aug. 23, 1939, \&, sn., sl. (no. $1623 \varepsilon$ ).

4. Beauvechain, S.E. of Louvain: July 28, 1929, $\delta$, sn. (no. $480 \beta$ ); Sep. 8, 1929, 2 juv. ôे $\delta$, sn. (nos. $480 \delta$ and $\gamma$ ); Dec. 12, 1930, $\delta$, sn., sl. (no. $481 \delta$ ); Dec. 18, 1930, $q$, sn., sl. (no. $481 \varepsilon$ ); Dec. 24,1930 , $q$ and $\hat{\delta}$, sn., sl. (nos. $481 \varepsilon$ and $\zeta$ ); Nov. 15, 1932, $\delta$ and juv. $\delta$, sn., sl. (nos. $482 \delta$ and $\gamma$ ); April 7, 1936, sl. (no. 2801); Nov. 6, 1938, $\widehat{o}$, sn., sl. (no. $482 \zeta$ ); May 20, 1939, $q$ and $\hat{\delta}$, sn., sl. (nos. 1623, and $1623 \beta$ ).

5. Wavre, S.W. of Louvain: March 15, 1929, sn. (no. 480).

6. Near Court-St.-Etienne, S.W. of Wavre: Aug. 1, 1939, juv. $\delta \hat{\delta}$, sn., sl. (no. $1623 \gamma$ ); Aug. 15, 1939, $\hat{\delta}$ and juv. $\hat{\delta}$, sn., dam. sl. (nos. 1624, and 1624 $\beta$ ); Aug. 19, 1939, juv. ㅇ, sn., dam. sl. (no. 1626); Aug. 21, 1939, sl. (no. $1626 \beta$ ); Aug. 22, 1939, 2 tै $\hat{\delta}$, sn., sl. (nos. $1626 \gamma$, and $1626 \delta$ ); Dec. 2, 1939, $\hat{\delta}$, sn., sl. (no. $1626 \zeta)$.

7. La Quenique, near Court-St.-Etienne: Aug. 11, 1939, $\hat{\delta}$, sn., dam. sl. (no. $1623 \zeta$ ); Aug. 15, 1939, ồ, sn., dam. sl. (no. $1624 \gamma$ ) -2 juv. $Q \bigcirc$, sn., dam. sl. (nos. $1624 \delta$ and $\varepsilon$ ); Aug. 16, 1939, 2 juv. $\delta \hat{~} \delta$, sn., dam. sl. (nos. $1624 \zeta$, and 1625); Aug. 17, 1939, 2 juv. $\delta \hat{~} \delta$, sn., dam. sl. (nos. $1625 \beta$ and $\gamma$ ) - juv. $q$, sn. (no. $1625 \delta$ ); Aug. 18, 1939, juv. $\varnothing$ and juv. $\delta$, sn. (nos. $1625 \varepsilon$ and $\zeta$ ); Aug. 26, 1939, + , sn., dam. sl. (no. $1626 \varepsilon)$.

8. Grandsart, Limal, S.W. of Wavre: Aug. 4, 1943, ô, sn., dam. sl. (no. 4331).

9. Bois de Buis, Namur: July 12, 1947, juv. đૈ, sn., sl. (no. 6422).

\section{SENCKENBERG MUSEUM, FRANKFURT AM MAIN}

Germany, west of the Rhine.

Nierstein, S. of Mainz: $2 \delta \delta$ and 1 \&. sn. (nos. 6110, 6111 , and 6112).

Germany, east of the Rhine.

1. Vilbel, N. of Frankfurt am Main: Aug. 31, 1910, 2 sn. (nos. 6114, and 6116) - sn., dam. sl. (no. 6117).

2. Ginheimerhöhe: March 29, 1911, $\delta$, sn., dam. sl. (no. 1624).

3. Schwanheimer Land: Sep. 23, 1910, sn. (no. 6107). 


\section{RIJKSMUSEUM VAN NATUURLIJKE HISTORIE, LEIDEN}

The Netherlands, southern part of the province of Limburg.

1. Heerlen: 1880, juv. o, sn. (no. 13235).

2. Oud-Valkenburg: Aug. 31, 1938, juv. ô, sn., sk. (no. 3526) - juv. $\delta$, sn., (no. 3525) - juv. $\hat{\delta}$, sn., dam. sl. (no. 3524) - juv. $\hat{\delta}$, sn. (no. 3522) - juv. $Q$, sn., (no.

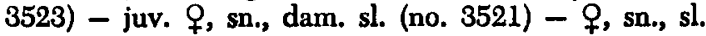
(no. 3520).

3. Houthem, W. of Valkenburg: Oct. 23, 1924, ㅇ, sn., sl. (no. 1353); Jan. 1, 1925, ㅇ, sn., sl. (no. 1374); July 25, 1925, ô, sn., sl. (no. 1408); 2 juv. ổ ồ, sn., dam. sl. (nos. 1410 a and b); Aug. 5, 1925, $2 \hat{o} \hat{\jmath}$, sn., sl. nos. 1411 a and b); Sep. 29, 1925, ô, sn. sl. (no. 1422); Aug. 10, 1926, ð’, sn., dam. sl. (no. 1516a) - 3 \% , sn., sl. (nos. 1516 b and c; 1517 a); Aug. 11, 1926, juv. ठิ, sn., dam. sl. (no. 1517 b) - ơ, sn., sl. (no. 1517c) - 2 우, sn., sl. (nos. $1517 \mathrm{~d}$ and e); Aug. 14, 1926, $\delta$, sn., sl., (no. $1518 \mathrm{a}$ ) -2 2 \% , sn., sl. (no. $1518 \mathrm{~b}$ and c) - $\hat{\sigma}$, sn., sl. (no. 1524 c); Aug. 18, 1926, 2 ô ô, sn., sl. (nos. $1522 \mathrm{~b}$ and c); Aug. 23, 1926, 2 우, sn., sl. (nos. $1524 \mathrm{a}$ and b) $-\delta$, sl. (no. $1524 \mathrm{c}$ ); Aug. 27, 1926, 2 ô ô, sn., sl. (nos. 1526 a and b); Sep. 9, 1926, ô, sn., sl. (no. 1529 a) - $\&$, sn., dam. sl. (no. 1529 b) - juv. $\delta$, sn., dam. sl. (no. 1529 c); Sep. 19, 1926, sn., dam. sl. (no. 1522 a).

4. Sibbe: Nov. 6, 1952, $q$, sn. (no. 11739).

5. Banholt-Mheer: Oct. 3, 1950, ô, sl. (no. 10863); Oct. 18,1957 , sn. (no. 16155).

6. Heer: Aug. 16, 1947, juv. $\delta$, sn. (no. 8617); Aug. 13, 1954, ठૈ, sn., sl. (no. 12398); Sep. 27, 1954, ठ̂, sn., sl. (no. 12418).

\section{Germany.}

1. Near Brunswick: May 21, 1949, $ᄋ$, sl. (no. 12486); July 11, 1949, juv. ô, sl. (no. 12493); Sep. 14, 1949, 4 ô $\hat{o}$, sl. (nos. 12483-12485, 12487) - ㅇ, sl. (no. 12482); April 24, 1950, ô, sl. (no. 12481); Aug., 1951, ㅇ, sn., sl. (no. 12475); July, 1952, đ̊, sn., sl. (no. 12474) - ô, sl. (no. 12474); Oct. 31, 1952, ㅇ, sl. (no. 12475) -2 ô ô. sl. (nos. 12489 and 12490) -, , sl. (no. 12488) - sl. (no. 12480) - juv., sl. (no. 12492).

2. Halle an der Saale: April 1913, $\delta$ and $\wp$, sn., dam. sl. (nos. $592 \mathrm{a}$ and $\mathrm{b}$ ).

3. Saxony: sn. (Cat. Jentink 1888, b); 1836, juv., sn. (Cat. Jentink 1888, h).

4. Thüringia: 1866, juv., sn. (Cat. Jentink 1888, d).

Hungary.

1. Budakeszi: July 5, 1935, ô, sn., sl. (no. 2433).

2. Locality unknown: 1934, ¿ै, sn., sl. (no. 4277).

\section{INSTITUT ZOOLOGIQUE ED. VAN BENEDEN LIEGE}

Belgium.

Lantin, N.N.W. of Liège: Jan. 10, 1925, sl. (no. 10967).

Germany.

Thüringia: sn., (no. 8129).
BRITISH MUSEUM (NATURAL HISTORY), LONDON

Belgium.

Tirlemont: Nov. 14, 1908, §, sn., sl. (no. 8.1J.23.1); Dec. 23, 1908, ô, sn. (no. 8.11.23.2).

France.

Near Strasbourg: April 31, 1883, ô, sn., sl. (nos 19.77. 2257-2258).

Germany, west of the Rhine.

Nieder Ingelheim, S. of Mainz: May 7, 1908, ô, sn. (no. 8.11.2.38); June 4, 1908, $\partial$, sn., sl. (no. 8.11.2.39); June 5, 1908, $\hat{\sigma}$, sn. (no. 8.11.2.40); June 8, 1908, ô,

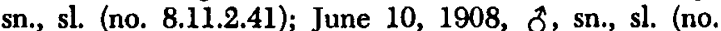
8.11.2.42); June 11, 1908, ô, sn., sl. (no. 8.11.2.43).

Germany, east of the Rhine.

1. Magdeburg: Oct. 5, 1892, 2 sn., dam. sl. (nos. 92.12.1.24 and 25); Sep. 9, 1892, sn. (no. 92.12.1.27); sn. (no. 92.12.1.26).

2. Birkenhain: Oct. 10, 1897, đิ, sn. (no. 20.5.23.1).

3. Saxony: Sep. 17, 1884, ㅇ, sn., sl. (nos. 19.7.7.26062605); Oct. 4, 1897, ơ, sn., sl. (no. 97.12.4.33).

4. Locality unknown: April, 1871, sn. (no. 79.9.25.35).

Hungary.

1. Szolnok: sn., dam. sl. (no. 21.2.5.1).

2. Rábé: sn. (no. 11.1.14.10).

Yugoslavia.

1. Zemum, Szerem near Belgrado: Sep. 28, 1933, ô and Q, sn., sl. (nos. 34.7.1.24 and 25).

2. Novi Banovce, Szerem: April 11, 1930, ô, sn., sl. (no. 33.4.4.11).

3. Pančevo: Oct. 21, 1934, juv. $\delta$, sn. (no. 34.11.5.3).

Russia.

1. Volsk, Saratov: May 28, 1927, 2 sn., sl. (nos. 28.4.4.38 and 39); May 30, 1927, juv., sn. (no. 28. 4.4.37) - juv., sn., dam. sl. (no. 28.4.4.40)

2. Vladikavkas, Caucasus: May, 1923, sn., sl. (no. 26.2.2. 20).

3. Sarpasteppe: March 15, 1911, sn., dam. sl. (no. 11. 11.9.5); March 18, 1911, sn., dam. sl. (no. 11.11.9.6).

4. Volga: sn., sl. (no. 7.1.1.159).

5. Kazan: \&, sl. (no. 19.7.7.2306).

Europe.

Locality unknown: $\wp$, sn., dam. sl. (no. 44.10.12.1).

Locality unknown: sn. (no. 58.9.12.6).

\section{ZOOLOGISCHE STAATSSAMMLUNG, MUNICH}

Germany, west of the Rhine.

Alzey, S. of Mainz: 1912-1913, 15 juv. ô ô, sl. (nos. $1913 / 586,598,611,615,729,735,741,749,753,757$, 759, 760, 762, 763, 765) - 30 ad. ôे ठैं, sl. (nos. 1912/777; $1913 / 294,295,301,305,313,314,315,316,317,318$, $319,320,321,323,578,600,619,638,658,708,710$, $711,712,713,715,719,728,768,848)-14$ juv. 우우, sl. (no. $1913 / 574,582,588,595,622,624,633,660,780$, $781,786,789,790,793$ ) -18 ad. 우, sl. (no. 1913/309, $567,589,613,627,628,629,652,653,656,724,727$, $788,846,849,1108,1109$ ) - 1 sl. (no. 1913/646).

Germany east of the Rhine.

Schönebeck an der Elbe: Sep. 3, 1934, q, sn., (no. 1939/ 102). 


\section{MUSEE ZOOLOGIQUE DE L'UNIVERSITE ET DE LA VILLE, STRASBOURG}

Germany, west of the Rhine.

1. Stutzheim, $12 \mathrm{~km} \mathrm{N.W.} \mathrm{of} \mathrm{Strasbourg:} \mathrm{April} \mathrm{1949,}$ $3 \delta \delta$, sn., sl. (nos. $1888 \mathrm{a}, \mathrm{b}$, and c) -2 OQ, sn., sl. (no. $1888 \mathrm{~d}$ and e) -2 sl. (no. $1888 \mathrm{f}$ and $\mathrm{g}$ ).

2. Fort bei Lingalsheim, Alsace: sl. (no. s, Zool. Anat. L. 302).

Germany, east of the Rhine.

1. Badersleben, S. of Magdeburg: skulls only, sex unknown, 2 juv. (nos. 1424, 1430) -46 ad. (nos. 31, 32,
$33,157,158,159,184,298,383,408,447,448,465$, $481,528,672,788,831,871,1397-1405,1416-1422$, 1425-1429, 1431, 1432, 1433, 1435, 1437, 1733).

2. Merseburg, S. of Halle an der Saale: skulls only, sex unknown, 47 ad. (nos. 649, 1811-1843, 1863-1875).

3. Saxony: sl. (no. 124).

Poland.

1. Proskau, S. of Opole (= Oppeln): 3 $\%$, sl. (nos. 1776-1778); 4 đิ ô. sl. (nos. 299, 280, 1852, r); sl. (no. 2590).

2. Silesia: $2 \hat{\partial} \hat{\partial}$, sl. (no. 212,213 ).

\section{A DISCUSSION ON THE SYSTEMATIC VALUE OF CERTAIN CHARACTERS OF CRICETUS CRICETUS}

\section{VARIATION IN THE COLOUR PATTERNS OF CRICETUS CRICETUS}

The 150 specimens of the common hamster at hand show the following variations in the colour of the coat.

1. The coat colour of the dorsal surface. - In the original description of Cricetus cricetus canescens, Nehring $(1899$, p. 1) noted that his new "variety" of the hamster from Fexhe-Slins (west of the Meuse, S.E. of Tongres, Belgium) is to be distinguished from the typical form by its dark mouse-greyish colour of the upper parts. Quite correctly Novikov (1935, p. 302) remarked that this dark colour is common in young individuals of the hamster. In my material the juveniles and young specimens are darker coloured than the adults. I am under the impression that on a whole the adult specimens from central Europe have more reddish brown and yellowish brown shades in their upper parts than those from the Netherlands and Belgium, the sprinkling of black-tipped hairs in the latter being more pronounced. These differences are small and in this character many adult specimens from the Netherlands and Belgium are indistinguishable from those of central Europe, so that in my opinion the colour of the upper parts is not sufficiently constant to be used for the distinction of the two subspecies.

2. The presence of a small spot of white hairs on the crown between the ears. - In the literature dealing with the hamster I did not find data on this colour variation. The extent of the white colour varies from a few white hairs only to a distinct spot. Of 54 specimens from the southern part of the Netherlands province of Limburg 42 have no trace of this white spot; 9 specimens have only a few white hairs there (A. no. 2063, \&; L. no. 1353, $\& ; 1410$ a, $\delta$;

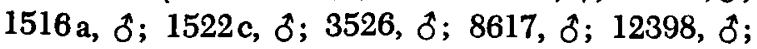
$\left.12418, \delta^{\dagger}\right)$, while 3 specimens show a distinct pure white spot (L. no. $1411 \mathrm{a}, \hat{\delta} ; 1526 \mathrm{a}, \hat{\delta} ; 3522, \hat{o}$ ). Of 41 specimens from Belgium 22 show no trace of a white spot; in 10 specimens the spot consists of a few hairs only (Br. no. $481 \delta, \delta ; 482 \gamma, \delta ; 1623 \gamma, \hat{\delta}$; $1624 \beta, \delta ; 1624 \delta$, ᄋ; $1624 \zeta, \delta ; ; 1625$, ठै; $1625 \gamma, \delta$; $1626 \gamma, \delta ; 1626 \varepsilon$, + ); in 6 specimens the spot is distinct but small (Br. no. $482 \delta, \delta ; 1623 \beta, \delta ; 1624 \gamma, \hat{\sigma}$; $1625 \beta, \delta ; 1625 \varepsilon$, $+; 6422, \delta$ ), while in 3 specimens the white spot has a length of $10 \mathrm{~mm}$ and a breadth of about $5 \mathrm{~mm}$ (Br. no. $480 \delta, \hat{\delta} ; 480 \gamma, \hat{\delta} ; 1623 \zeta, \hat{\delta})$. In 2 specimens from Zemum, Yugoslavia, there is a small white spot between the ears (B.M. no. 34.7.1. $24, \delta ; 34.7 .1 .25$, $q)$. In the more than 50 specimens from the other localities in Europe (see: material examined) I did not observe this colour variation at all.

From these data it must be concluded that the presence of a white spot between the ears mainly occurs in the populations of the hamster occurring in the Netherlands and in Belgium. The 2 specimens from Yugoslavia form an exception for the hamsters collected in the centre of the range of the species. Furthermore it appears that the white spot is better developed and can be observed more frequently in males than in females: in my material no less than 27 males and only 6 females show this character.

3. The presence of a small spot at the base of the thigh. - WeTtSTEIN (1927, pp. 75-76) noted that in the seven specimens of the hamster from lower Austria examined by him the small spot at the base of the thigh was absent or obsolete: "Als Hauptunterschied gegenüber den deutschen Hamstern könnte man anführen, dass bei allen mir vorliegenden 7 Bälgen der kleine helle, gelblichweisse Fleck vor dem Hinterschenkel nur aus einigen wenigen, mit dunklen Haaren untermischten weisslichen Haaren 
besteht, sodass dieser Fleck, (bei den jungen Individuen etwas deutlicher) schwer auffindbar und bei einigen Stücken sogar fast verschwunden ist. .... Bei den deutschen Hamstern dagegen soll dieser Fleck die Ausdehnung und Reinheit des hellen Fleckes an der Ohrbasis haben, was bei keinem der niederösterreichischen der Fall ist".

When examining this character in my material I came to the conclusion that the small spot at the base of the thigh greatly varies in size as well as in the intensity of the colour, which in some specimens is white, in others whitish, yellowish, yellowish white, or yellowish brown. Of 52 specimens from the Netherlands province of Limburg the following variations in the intensity of the colour of this spot were found: (a) distinct on both thighs, 35 specimens; (b) absent from both thighs, 1 juvenile; (c) obsolete on both thighs, 7 specimens; (d) distinct on right, obsolete on left thigh, 3 specimens; (e) absent from right, distinct on left thigh, 3 specimens; (f) obsolete on right, distinct on left thigh, 2 specimens; $(g) a b-$ sent from right, obsolete on left thigh, 1 juvenile. Until now no Netherlands specimens of the hamster have been found in which a spot, either distinct or obsolete, is present on the right thigh but absent from the left.

Of 40 Belgian specimens 34 possess a distinct spot at the base of both thighs; in 3 the spot on the right thigh is distinct, but that of the left is obsolete; in 3 specimens the spot on the right thigh is obsolete, while that on the left is distinct. All the other combinations are lacking in the material examined.

Of 15 specimens from the west side of the Rhine (Nierstein, 3; Nieder Ingelheim, 6; Stutzheim, 5; Strasbourg, 1), 6 possess a distinct spot at the base of both thighs; of 8 the spot is obsolete on both thighs, while in 1 the spot is absent from the right thigh but distinct on the left.

Three specimens from Vilbel, N. of Frankfurt am Main, present the following combinations: the spot is obsolete on both thighs, the spot is absent from both thighs, the spot is distinct on the left thigh but absent from the right. In the only specimen from Ginheimer Höhe near Frankfurt am Main the spot is absent from both thighs, while in the only specimen from Schwanheimer Land the spot is distinct on the right thigh, but obsolete on the left.

Of 18 specimens from central Germany, 13 have a distinct spot on both thighs; in 3 both spots are obsolete; in 1 the spot is obsolete on the right thigh, but distinct on the left; in 1 specimen the spot is obsolete on the right thigh but absent from the left.

Of 4 specimens from Hungary, 2 have a distinct spot on both thighs; in 1 both spots are absent, while in 1 specimen they are very obsolete. Of 4 specimens from Yugoslavia only 1 has a distinct but small spot on both thighs, while in the 3 others both spots are obsolete; the only specimen from near Bucharest in this respect is similar to the 3 last-mentioned Yugoslav specimens.

Of 9 specimens from Russia, 3 have a large distinct spot on both thighs; in 3 the spot on both thighs is small but distinct, and in 1 they are obsolete; in 2 specimens the spot is absent from both thighs.

From the above-mentioned data no definite conclusion can be drawn as to the question whether this character has any systematic value. Far more material is needed from the whole range of distribution of the species to decide the question, but as far as can be concluded from the material at hand there is an indication that in the Netherlands and Belgium a distinct spot on the base of both thighs is more frequently found than in the other countries.

4. The white streak in the median line of the throat extending from the chin backward, the white cuffs on the fore legs, and the white spot on the breast. - Figures 1-10 show the variability and the extension of the white colour of the just-mentioned parts. Figure 1 (L. no. 4277: Hungary) represents the white parts as they occur in the typical hamster: the white streak in the median line of the throat is short and blunt, the black fore legs have only the feet white, and the ventral parts are entirely black or slate coloured. As pointed out on page 188 WEPNER (1936) was the first author who drew attention to the fact that the western hamster, Cricetus cricetus canescens, shows marked differences from this typical pattern. I have studied these patterns in the available material and I will now give a description which goes into considerably more detail than that given by WEPNER.

a. The white streak in the median line of the throat extending from the chin backward. - The position of the posterior limit of this white streak is very variable in the hamster occurring in the Netherlands and in Belgium (Figs. 3-10). Also the shape and the size are subject to great variation, the streak being broad and blunt in some specimens (Figs. 4 and 10), narrow, pointed and long in others (Figs. 3, 6, and 9), while all kinds of transition may occur (Figs. 5, 7, and 8). For this reason it is difficult to check WEPNER's (1936, p. 256) general statement: "Der weisse Fleck unterhalb der Schnauze ist bei canescens weiter ausgezogen und läuft auf dem Hals spitz aus". The variation in shape and size of this white streak makes it practically impossible to distinguish 

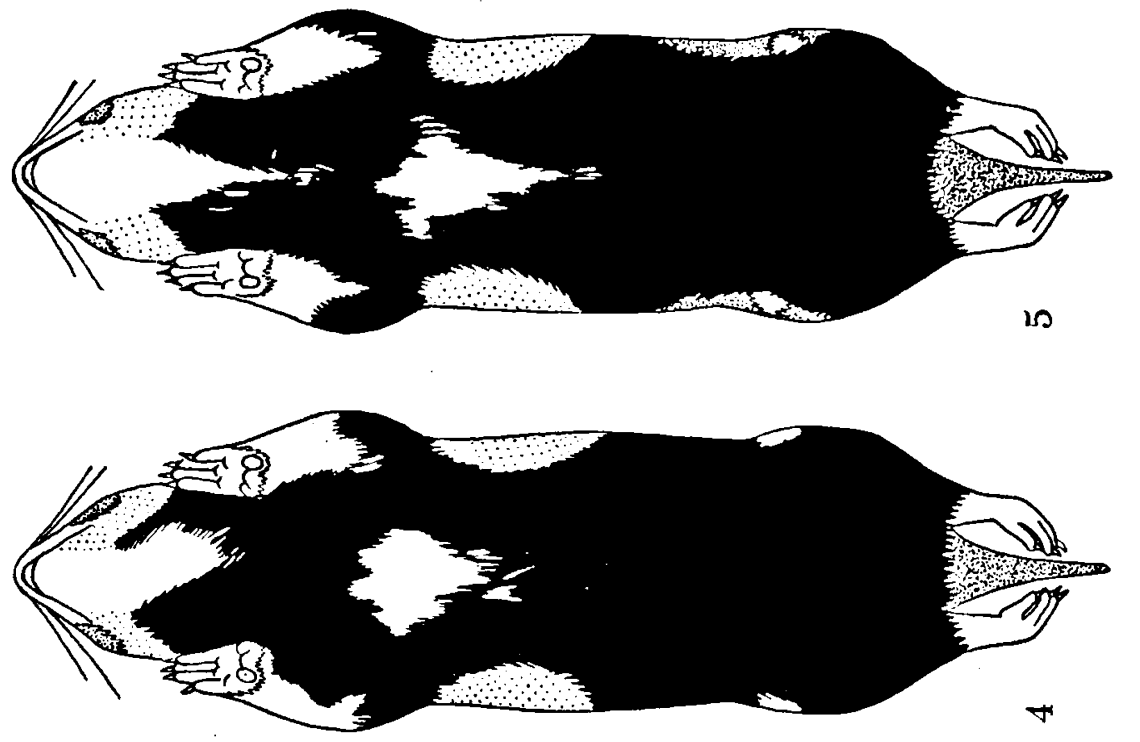

茶密

ง

रेष्ठ

政

运密

完

䗆

苌

$-\frac{0}{5}$

$1 \stackrel{200}{\#}$

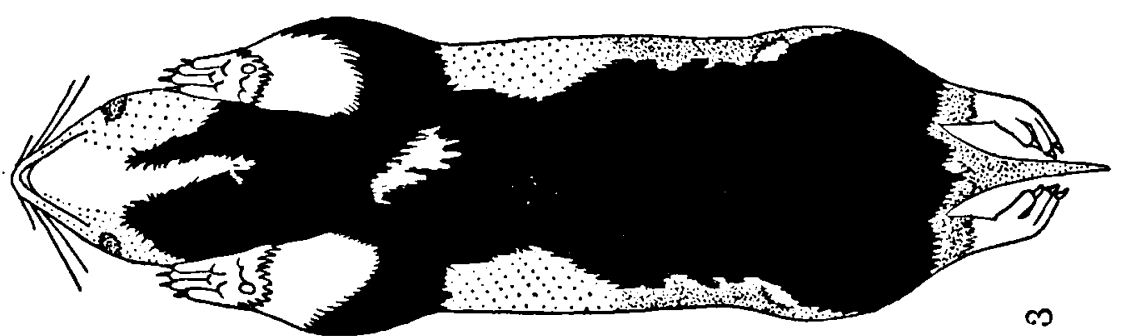

$\dot{\hat{\Theta}}^{\circ}$

象定

है

政

的总

है ᄋ

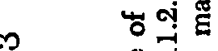

800

苾范

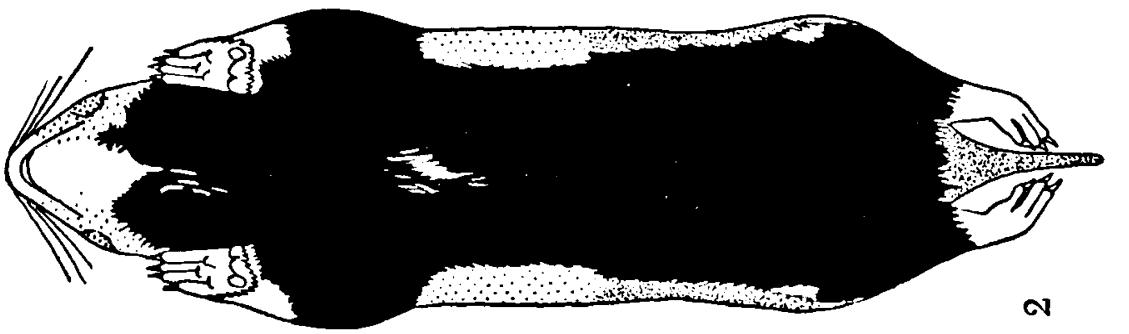

สี

突若

电

岁若宫

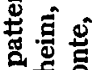

密

웅

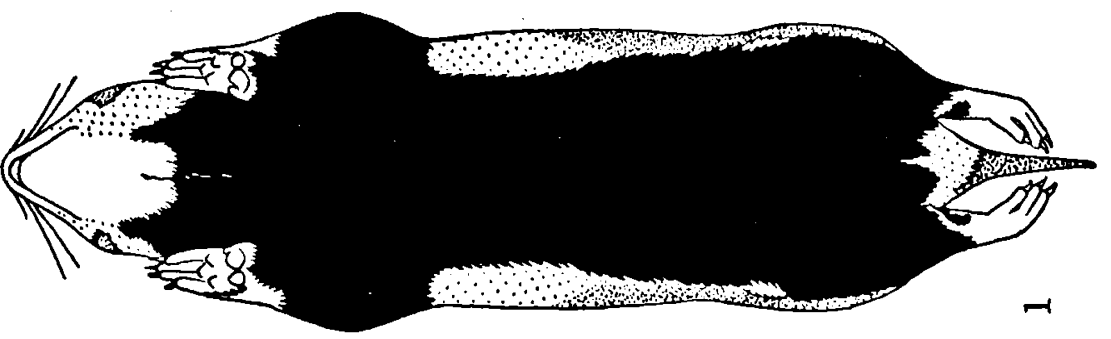

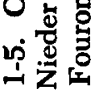

巤星 

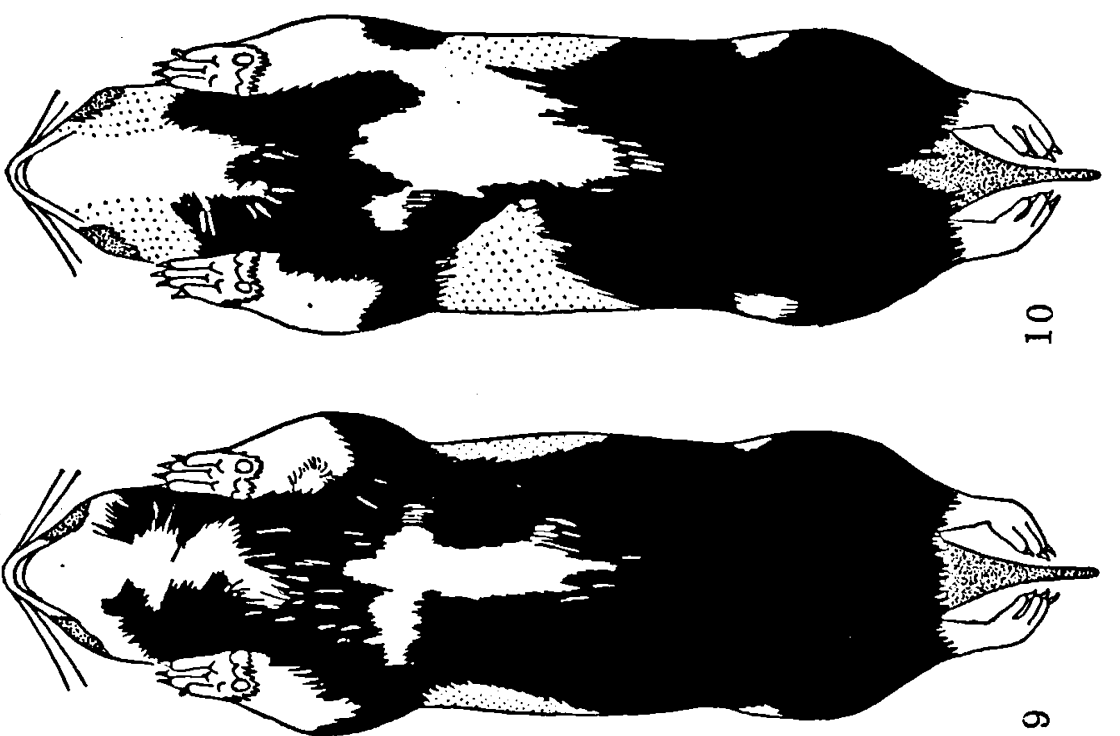

ซึّ

寻

ثี่

ตี๊

$\varepsilon \dot{8}$

눈

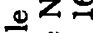

要焉宙

๑ है

苛

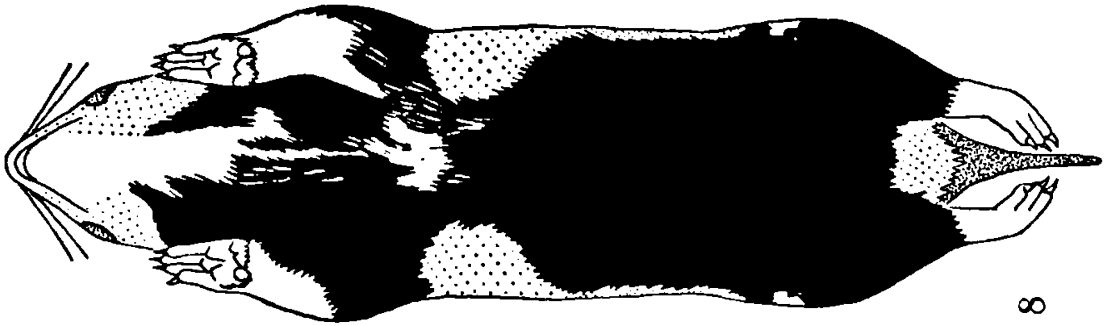

已.

논

है

范家

हैँ

ธิ

造范

苟 हี

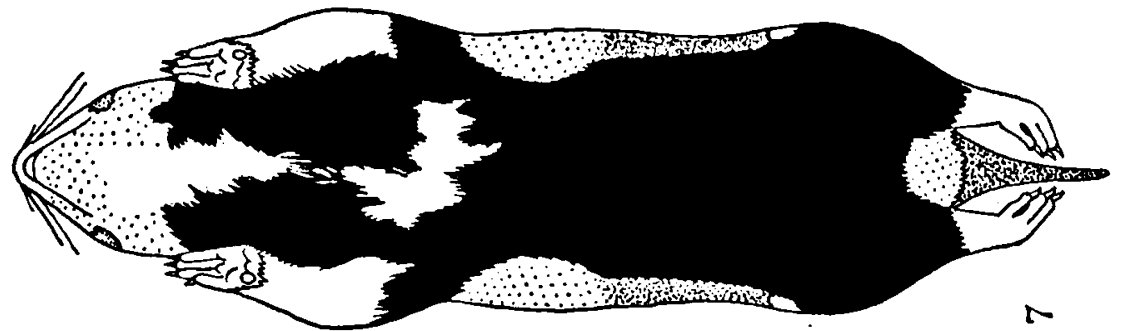

菏

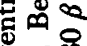

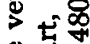

吾驾

ठํㅠㅇ

园

要要

亏ํํㄹ

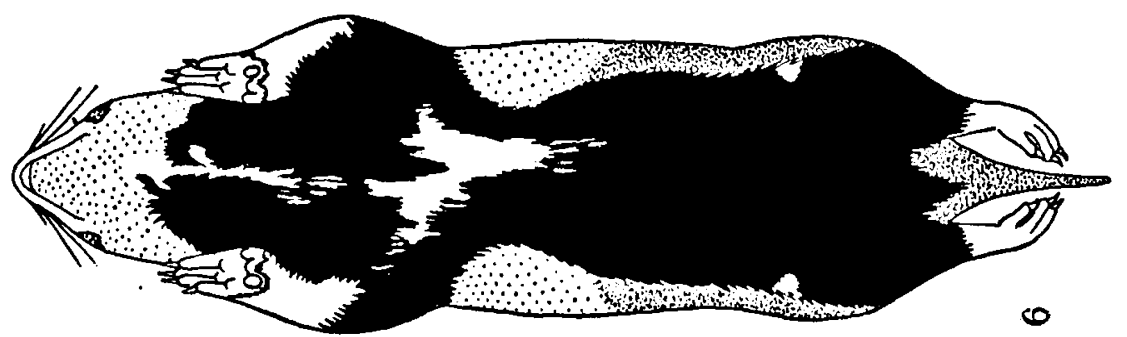

อิ

車

证的 
two sharply defined groups. In view of the material examined I come to the conclusion that the shape and extent of the white streak on the throat offers no character of systematic value to distinguish the hamster occurring in the Netherlands and Belgium from those from the other countries: in the populations from the Netherlands and Belgium as well as in those from other countries a pointed streak occurs more frequently than a blunt streak; a narrow, pointed and long streak (Figs. 3, 5, and 6) occurs in both areas, though more frequently in the Netherlands and in Belgium, while large-sized streaks (Figs. 7, 8, and 9) have been found only in material from the Netherlands and Belgium.

b. The white cuffs on the fore legs. - In the typical form the fore feet are white above, the white colour extending for a small distance on the wrist, the larger part of which is black (Figs. 1 and 2). The specimens from the Netherlands and from Belgium all have the fore legs partly or entirely white (Figs. 310 ), at least on the ventral and outer surface, in none of them the white colour occupies as small an area as in most specimens of the typical form. The extent of the white colour of the fore legs is very variable, so that hardly two specimens are identical in this respect; in many specimens the length of the white cuff is differently developed on the two fore legs (Figs. 4, 6, 8, and 10). In a few specimens the white colour of the cuff is connected with the white patch on the breast (see under c; Fig. 10).

However, the white cuff is not restricted to hamsters from the Netherlands and Belgium: it is also found in specimens from other countries. As to these countries, there is a difference between the populations in Germany east of the Rhine, in Hungary and in Yugoslavia on one hand, and those in Germany west of the Rhine and in France on the other. Whereas in the former group there are far more specimens without cuffs, in the latter group the majority of the specimens show more or less distinct white cuffs (although extending only to about half the length of the fore legs). It is interesting to note that in the 9 specimens from Russia I had at my disposal, only 3 lack cuffs, whereas the other 6 have more or less distinct white cuffs, which do not extend beyond the anterior half of the fore legs. Unfortunately the number of Russian specimens is too small to allow definite conclusions.

Concluding from these facts I would tend to say that because of the overlapping variation the presence or absence of these white cuffs on the fore legs of the hamster do not constitute a character of subspecific value: whereas in my material white cuffs extending well over the half of the fore legs occur exclusively in specimens from the Netherlands and Belgium, white cuffs extending only to about half the length of the fore legs occur in specimens of virtually all countries.

c. The white spot on the breast. - As mentioned on page 189 , the irregular white spot or patch on the breast of the hamster, varying from a few hairs only to a large patch, occurs in all examined specimens from the Netherlands and Belgium (Figs. 2-10). In some specimens this white spot is connected with the median white streak on the throat (Fig. 7: Br. no. 4331, ơ; Fig. 8: L. no. 1411 a, $\delta$; the specimens Br. $480 \delta, \delta$, Br. $1623 \beta$, $\delta$, Br. $1623 \gamma, \delta$, Br. $1624 \delta$, + ,

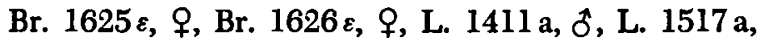
O, show approximately the same pattern). In other specimens the white patch of the breast is connected with the white cuff of the left fore leg (a tendency to this connection can be observed already in Fig. 8; it is obvious in Fig. 10: $\mathrm{Br}$. no. $1625 \beta$, $\hat{\sigma}$; the specimens L. $1411 \mathrm{a}, \hat{\delta}, \mathrm{L} .1410 \mathrm{~b}, \hat{\delta}, \mathrm{L} .1529 \mathrm{c}, \hat{\delta}$, have approximately the same pattern). That the white spot on the breast is no longer a character of systematical importance to separate the western hamster from the typical form (though it may have been so some decades ago), is shown by the fact that at present this white spot has been observed in many specimens from other countries than the Netherlands and Belgium (see page 189).

Of 54 specimens from the Netherlands, 8 have a small white spot on the breast, sometimes consisting of a few white hairs only; in 32 specimens this patch is rather well developed (Fig. 3); in 14 specimens there is a large white patch (Figs. 4-9), in 2 of these specimens the patch is connected with the median white streak on the throat, and in 3 with the white cuff of the left fore leg.

Of 41 specimens from Belgium, 6 possess a small white spot on the breast, in some examples consisting of a few white hairs only; in 12 specimens this spot is moderately well developed; in 23 specimens a large white patch is present, 6 of these having this patch connected with the median white streak on the throat, in 1 it is connected with the white cuff of the left fore leg, and in 1 the breast patch is almost confluent with both the white streak of the throat and the white cuff of the fore leg (B.M. no. 8.11.23.2, $\hat{o}$ ).

Of 14 specimens from west of the Rhine (Nierstein, Stutzheim, Nieder Ingelheim, und Strasbourg), 5 show no trace of a white spot on the breast, in 3 the spot consists of a few white hairs only, in 5 there is a moderately well developed patch, while in only one specimen (St. no. $1888 \mathrm{c}, \hat{\delta}$ ) it is large and to a 
slight degree connected with the white cuff of the left fore leg.

Of 25 specimens from Germany east of the Rhine, 15 have no trace of a white spot on the breast; in 8 specimens the white spot consists of a few hairs only; in 2 the spot is moderately well developed.

In 4 specimens from Hungary no trace of a white spot on the breast is found. Of 5 specimens from Yugoslavia not one has a white spot; in one there are a few white hairs. Of 9 specimens from Russia, 7 show no trace of a white spot on the breast; in 2 the white spot is present but consists of a few hairs only.

d. The constriction of the black part of the ventral surface. - The roundish light buff areas, extending backward from the axilla, are separated by the black colour in the ventral surface. The normal configuration of these roundish areas is shown in Figs. 1, 2, and 9 , where the black area has about the same width throughout. There are, however, specimens in which the black colour between the light buff areas shows a noticeable constriction (Figs. 8 and 10), showing that in such specimens the area of the black colour of the under parts is not only reduced by the extension of the various white areas but also by that of the light buff regions. It is very difficult to characterize this constriction quantitatively. I divided my material in three groups: (1) specimens without constriction (Figs. 1 and 2), (2) specimens with a moderately distinct constriction (Figs. 3-5, 7, and 9), and (3) specimens with a strongly developed constriction (Figs. 6, 8, and 10). Of 50 specimens from the Netherlands, 25 belong to group (2), and 25 to group (3). Of 41 specimens from Belgium, 7 belong to group (1), 29 to group (2), and 5 to group (3). Of 15 specimens from Germany west of the Rhine, 8 belong to group (1), and 7 to group (2). Of 20 speci- mens from Germany east of the Rhine, 11 belong to group (1), 5 to group (2), and 4 to group (3). Of 4 specimens from Hungary, 2 belong to group (1), and 2 to group (2). Of 5 specimens from Yugoslavia 3 belong to group (1), and 2 to group (2). Of the 9 specimens from Russia, 5 belong to group (1), and 4 to group (2). It seems therefore that the constriction is proportionally better developed in the hamsters from the Netherlands and Belgium than in those from other localities.

Summarizing the above-mentioned data concerning the white pattern of the coat colour of Cricetus cricetus and the facts concerning white patterns and melanistic forms referred to on page 189 of the present paper I would like to describe the situation as follows. Whereas in 1936 WEPNER could consider the white patterns to characterize the subspecies Cricetus cricetus canescens, this character has since presented us with a peculiar phenomenon which is rather uncommon in geographical races: it has expanded at the cost of the typical patterns in central Germany. At the same time the melanistic form seems to expand into Germany from the east. If this picture is true, the typical form may become increasingly rare, and might eventually disappear entirely. Hence, as long as this situation is changing I think one had better abstain from applying terms like subspecies or geographical race to this situation which is so strikingly different from the usual situations in which these terms are applied.

At least this is my conclusion as far as colour patterns are concerned. In the next section I shall show that there is a certain amount of evidence that what is no longer possible on the basis of colour patterns may well be possible on the basis of a certain skull character.

\section{VARIATION IN THE SKULL OF CRICETUS CRICETUS}

For a comparison of the skulls of the hamster occurring in the Netherlands and Belgium with those from other countries the following measurements were taken with a vernier calliper to the nearest tenth of a millimeter. (1) Condylobasal length: least distance from the posteriormost projections of the exoccipital condyles to the anteriormost point of the premaxillary bones between the incisors, therefore the distance between condyles and prosthion. (2) Basal length: distance from the basion (the anteriormost inferior border of the foramen occipitale magnum) to the prosthion. (3) Post palatal length: distance between the posteriormost median border of the palate (the staphylion) to the basion. (4) Length of the foramen incisivum (Fig. 11). (5) Length of the palate: from the posteriormost border of the foramen incisivum to the staphylion (Fig. 11). (6) Length of nasals: greatest diagonal length of the nasal; if the two nasals are not equal in length, then the mean of the two lengths is taken. (7) Zygomatic breadth: greatest distance across the squamosal portion of the zygomatic arches. (8) Mastoid breadth: greatest distance across the mastoid processes. (9) Breadth of braincase: distance between the two small openings (right and left) in the squamosal of the cranium. (10) Interorbital constriction. (11) Depth of rostrum, 


\begin{tabular}{|c|c|c|c|c|c|c|c|c|c|c|c|c|c|c|c|c|c|c|c|c|}
\hline \multirow{3}{*}{ 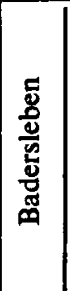 } & \multirow{3}{*}{ 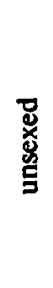 } & हू & \multirow{2}{*}{ 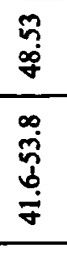 } & \multirow{2}{*}{ 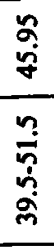 } & \multirow{2}{*}{$\frac{\widetilde{O}}{\stackrel{\Xi}{-}}$} & \multicolumn{3}{|c|}{ 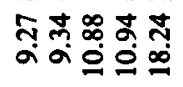 } & \multirow[b]{2}{*}{$\begin{array}{l}\vec{j} \\
\stackrel{\sim}{\sim} \\
\stackrel{\text { v }}{ }\end{array}$} & \multirow{2}{*}{ 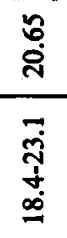 } & \multirow{2}{*}{ 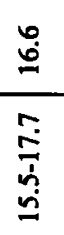 } & \multirow{2}{*}{ 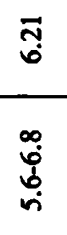 } & \multirow{2}{*}{ 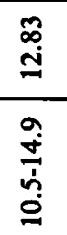 } & \multirow{2}{*}{ 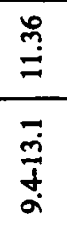 } & \multirow{2}{*}{ 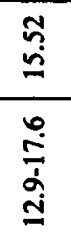 } & \multirow{2}{*}{ 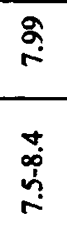 } & \multirow{2}{*}{$\frac{\stackrel{a}{r}}{\stackrel{a}{0}}$} & \multirow{2}{*}{ 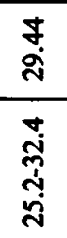 } & \multirow{2}{*}{ 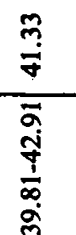 } & \multirow{2}{*}{ 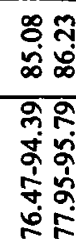 } \\
\hline & & 品 & & & & 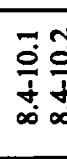 & जิ & 我 & & & & & & & & & & & & \\
\hline & & $=$ & $\mathcal{F}$ & ช & $F$ & $F$ & $\mathcal{F}$ & 共 & $\stackrel{\infty}{\infty}$ & Y & $\mathcal{F}$ & $\mathcal{F}$ & $\mathcal{F}$ & $F$ & $\mathcal{F}$ & $F$ & $F$ & $\bar{F}$ & $\bar{y}$ & $F$ \\
\hline \multirow{3}{*}{$\begin{array}{l}\text { 电 } \\
\text { 总 } \\
\text { 总 } \\
\sum\end{array}$} & \multirow{3}{*}{ 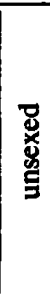 } & 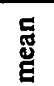 & $\underset{m}{m}$ & \begin{tabular}{l}
$\tilde{n}$ \\
\multirow{y}{*}{}
\end{tabular} & స్ & \multicolumn{3}{|c|}{ 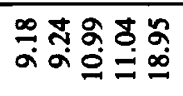 } & $\stackrel{\sim}{\text { ğ }}$ & 气ิ & $\frac{9}{5}$ & ?ึ & $\frac{0}{2}$ & $\stackrel{\infty}{:}$ & $\stackrel{\mathscr{\infty}}{\stackrel{\sim}{\emptyset}}$ & $\underset{\infty}{\exists}$ & $\underset{\infty}{\varnothing}$ & $\begin{array}{l}\tilde{\Upsilon} \\
\stackrel{\sim}{\sim}\end{array}$ & $\frac{\bar{a}}{\sigma}$ & 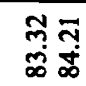 \\
\hline & & 总 & 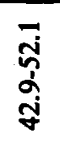 & $\begin{array}{l}m \\
\stackrel{0}{0} \\
o \\
\vec{y}\end{array}$ & $\begin{array}{l}\frac{0}{\pi} \\
\stackrel{+}{+} \\
=\end{array}$ & \multicolumn{3}{|c|}{ 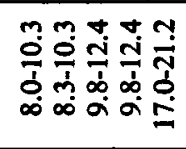 } & 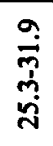 & $\begin{array}{l}\stackrel{a}{\vec{T}} \\
\infty \\
\infty \\
\infty\end{array}$ & $\begin{array}{l}\stackrel{m}{\infty} \\
\dot{d} \\
\stackrel{\dot{d}}{0}\end{array}$ & فे & $\begin{array}{l}\stackrel{0}{ \pm} \\
\stackrel{\dot{m}}{=}\end{array}$ & $\begin{array}{l}\stackrel{0}{\mathrm{~m}} \\
\text { +⿱ } \\
\stackrel{0}{0}\end{array}$ & $\begin{array}{l}\frac{i}{5} \\
\dot{j} \\
\dot{j}\end{array}$ & 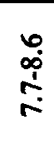 & 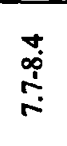 & $\begin{array}{l}\tilde{\hat{\sigma}} \\
\dot{0} \\
\stackrel{\phi}{0}\end{array}$ & 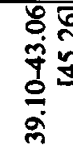 & 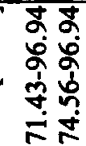 \\
\hline & & $\Rightarrow$ & 脑 & Z & $\vec{N}$ & $\forall$ & ষ & $\mathbb{N}$ & $\bar{N}$ & $\ddot{\theta}$ & $\ddot{\sim}$ & $\underset{N}{\mathbb{N}}$ & 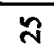 & 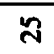 & $\approx$ & ম & $\check{\nu}$ & $\succsim$ & $\mathbb{N}$ & Z \\
\hline \multirow{6}{*}{$\frac{-\sqrt{N}}{\alpha}$} & \multirow{3}{*}{ 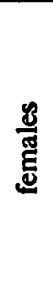 } & ⿷匚 & పా & 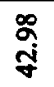 & $\stackrel{n}{\check{n}}$ & $\ddot{a}$ & $\stackrel{F}{\stackrel{\Xi}{\varrho}}$ & $\stackrel{\infty}{\stackrel{\infty}{\Xi}}$ & స़ & $\begin{array}{l}\infty \\
\stackrel{\infty}{\varrho}\end{array}$ & 气ِ & స్ & 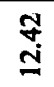 & $\stackrel{\infty}{\infty}$ & $\hat{a}$ & $\stackrel{\infty}{\stackrel{\circ}{\circ}}$ & $\stackrel{\infty}{\stackrel{2}{\sim}}$ & 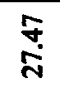 & $\stackrel{\infty}{\infty}$ & ڤ̊̊ \\
\hline & & 品 & 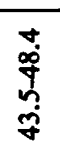 & $\begin{array}{l}\stackrel{0}{0} \\
\text { \&े } \\
m \\
\dot{q}\end{array}$ & $\frac{m}{a}$ & $\frac{\overline{0}}{\alpha}$ & $\frac{m}{\bar{p}}$ & $\frac{n}{\frac{1}{1}}$ & 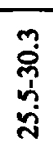 & $\begin{array}{l}\underset{\pi}{N} \\
\infty \\
\infty \\
\infty\end{array}$ & $\underset{\stackrel{+}{0}}{\stackrel{0}{0}}$ & $\begin{array}{l}n \\
0 \\
0 \\
0 \\
0\end{array}$ & $\stackrel{m}{\stackrel{m}{n}}$ & $\begin{array}{l}n \\
\bar{j} \\
\dot{0}\end{array}$ & 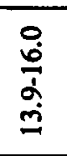 & $\begin{array}{l}0 \\
\infty \\
+ \\
+\end{array}$ & 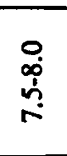 & 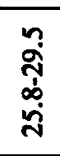 & 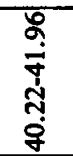 & 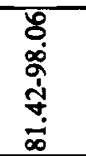 \\
\hline & & $a$ & $=$ & $\Rightarrow$ & $\Xi$ & $\stackrel{m}{m}$ & $m$ & $\simeq$ & 으 & $\cong$ & $m$ & $m$ & $\underline{z}$ & $\underline{m}$ & $m$ & $m$ & $\simeq$ & $=$ & $\Rightarrow$ & $m$ \\
\hline & \multirow{3}{*}{$\frac{83}{\frac{8}{\pi}}$} & छّ & ஷั & $\begin{array}{l}\infty \\
0 \\
\dot{\delta} \\
\dot{q}\end{array}$ & $\stackrel{\infty}{\text { aे }}$ & \multicolumn{3}{|c|}{ 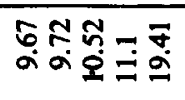 } & aे & $\stackrel{\infty}{\sim}$ & $\stackrel{F}{ \pm}$ & గ్ & $\stackrel{\infty}{\stackrel{\infty}{m}}$ & $\stackrel{\mathcal{Y}}{\mathcal{Z}}$ & ֻొ & $\stackrel{+\infty}{\sim}$ & $\stackrel{\infty}{\stackrel{2}{r}}$ & के & $\stackrel{\infty}{?}$ & $\begin{array}{l}\underset{\infty}{\infty} \overline{0} \\
\bar{\infty}\end{array}$ \\
\hline & & 鰙 & 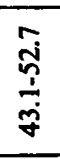 & $\begin{array}{l}\stackrel{0}{0} \\
\stackrel{8}{0} \\
\stackrel{8}{+}\end{array}$ & 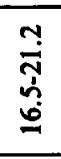 & \multicolumn{3}{|c|}{ 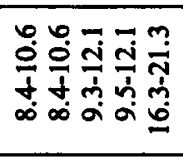 } & 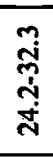 & 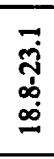 & $\begin{array}{l}n \\
\infty \\
0 \\
0 \\
0 \\
0\end{array}$ & $\begin{array}{l}\stackrel{0}{0} \\
\hat{b} \\
\dot{n}\end{array}$ & $\begin{array}{l}0 \\
\stackrel{0}{g} \\
\stackrel{g}{=}\end{array}$ & $\frac{m}{m}$ & $\begin{array}{l}\frac{0}{1} \\
\frac{1}{2}\end{array}$ & 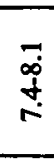 & 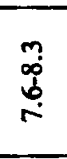 & 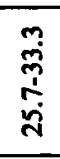 & 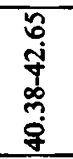 & 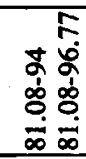 \\
\hline & & 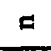 & $\stackrel{\infty}{ }$ & $\stackrel{\infty}{\stackrel{\infty}{2}}$ & $\stackrel{\infty}{\sim}$ & $\succsim$ & $\approx$ & $\mathbb{N}$ & $\simeq$ & $\stackrel{0}{ }$ & 9 & 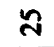 & $\mathbb{N}$ & $\mathbb{N}$ & $\mathbb{N}$ & 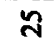 & 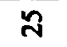 & $\approx$ & $\stackrel{\infty}{\sim}$ & $\approx$ \\
\hline \multirow{6}{*}{ 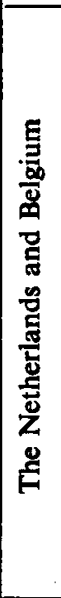 } & & 宽 & 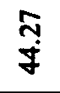 & $\frac{\hat{\alpha}}{\dot{\sigma}}$ & $\underset{⿱}{\stackrel{ \pm}{=}}$ & $\underset{\sigma}{\tilde{a}}$ & ஸे & $\stackrel{0}{\check{g}}$ & స్లి & 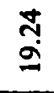 & 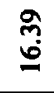 & कृ & $\frac{0}{\mathfrak{I}}$ & $\stackrel{n}{0}$ & $\underset{m}{\stackrel{m}{\Xi}}$ & $\stackrel{\circ}{\stackrel{\circ}{\circ}}$ & $\underset{\infty}{\overrightarrow{0}}$ & $\frac{n}{i}$ & $\stackrel{5}{\xi}$ & ัँ \\
\hline & $\begin{array}{l}\frac{8}{\pi} \\
\text { Eू }\end{array}$ & 惫 & $\begin{array}{l}\stackrel{\infty}{a} \\
\stackrel{+}{q} \\
\stackrel{+}{q}\end{array}$ & $\begin{array}{l}0 \\
\dot{f} \\
\infty \\
\dot{m} \\
\tilde{m}\end{array}$ & $\begin{array}{l}\stackrel{0}{0} \\
\text { ஸ் } \\
\text { ñ. }\end{array}$ & 足 & $\begin{array}{l}\dot{0} \\
\stackrel{1}{0} \\
\infty \\
\infty\end{array}$ & 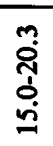 & 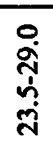 & 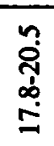 & $\begin{array}{l}\hat{\sigma} \\
\dot{\delta} \\
\dot{0}\end{array}$ & 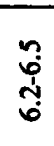 & 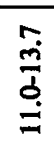 & $\begin{array}{l}\stackrel{0}{\mathbf{j}} \\
\frac{0}{0} \\
\text { 0 }\end{array}$ & 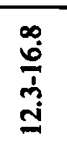 & 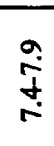 & 艿 & $\begin{array}{l}\stackrel{a}{\vec{n}} \\
\dot{0} \\
\dot{d}\end{array}$ & 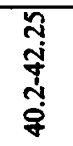 & $\begin{array}{l}2 \\
0 \\
0 \\
\vdots \\
\vdots \\
\dot{1}\end{array}$ \\
\hline & & $a$ & 9 & 9 & 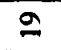 & $a$ & 9 & 2 & $m$ & \pm & $=$ & 9 & 9 & 9 & 9 & 9 & 9 & 9 & $=$ & 2 \\
\hline & & 蛋 & $\begin{array}{l}\because 0 \\
\dot{q}\end{array}$ & f & 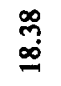 & $\frac{0}{0}$ & {$\left[\begin{array}{ll}\infty & \infty \\
\infty & \infty \\
\alpha & \infty\end{array}\right.$} & & స్ণి & ণ্ণి & $\begin{array}{l}0 \\
\infty \\
0 \\
0\end{array}$ & 守 & $\bar{m}$ & $\stackrel{\dddot{\dddot{N}}}{=}$ & ֻุ & $\underset{\sim}{\stackrel{\sigma}{0}}$ & $\stackrel{\infty}{\circ}$ & $\frac{n}{2}$ & $\stackrel{5}{q}$ & 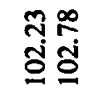 \\
\hline & $\frac{\mathscr{B}}{\mathbb{*}}$ & 惫 & $\frac{5}{\frac{5}{q}}$ & $\begin{array}{l}\infty \\
\stackrel{+}{+} \\
\stackrel{\sim}{0}\end{array}$ & 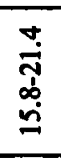 & $\stackrel{m}{\overline{7}}$ & $\begin{array}{l}0 \\
\stackrel{0}{0} \\
\text { o. }\end{array}$ & 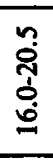 & 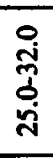 & 啇 & & 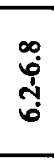 & 草 & $\frac{\mathfrak{I}}{\frac{1}{0}}$ & $\frac{\pi}{\frac{1}{3}}$ & $\stackrel{\vec{\infty}}{\stackrel{\infty}{n}}$ & 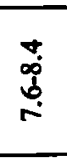 & 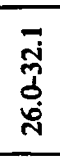 & \begin{tabular}{l} 
ธิ \\
\multirow{1}{\alpha}{} \\
aे
\end{tabular} & 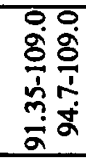 \\
\hline & & 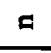 & 요 & นั & นి & ㄴ & : & $\approx$ & $\bar{N}$ & นి & ז & นั & 요 & ำ & นั & ำ & สั & i & \& & \& \\
\hline & & & 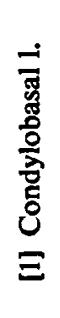 & 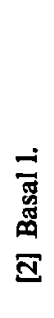 & 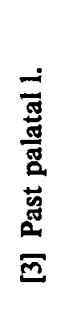 & 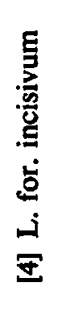 & 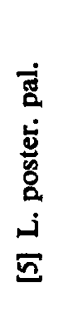 & 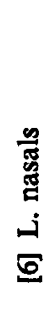 & 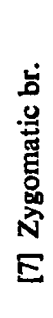 & 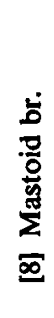 & 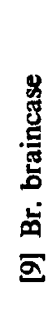 & 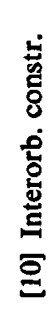 & 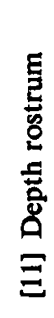 & 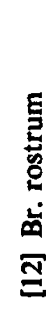 & 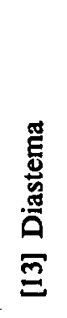 & 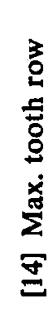 & 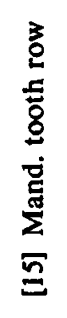 & 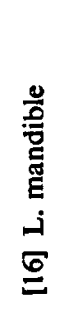 & 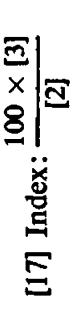 & 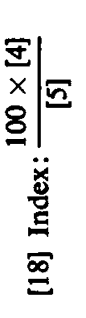 \\
\hline
\end{tabular}


measured with the lower bar of vernier calliper resting on the anterior border of the first molar, the upper bar held as vertically as possible. (12) Breadth of rostrum: greatest distance across the rostrum just before the infraorbital canals. (13) Diastema: distance from the posteriormost border of the incisive alveolus to the anteriormost border of the first molar. (14) Maxillary tooth-row: measured at alveolar border. (15) Mandibular tooth-row: measured at alveolar border. (16) Length of mandible: distance from the anteriormost border of the incisive alveolus to the posteriormost border of the condyles of the mandible.

From these measurements two indices have been calculated: for the position of the staphylion in the basis cranii, the index: $\frac{100 \times(3)}{(2)}$; for the ratio between the length of the foramen incisivum and the posterior part of the palate (Fig. 11), the index $\frac{100 \times(4)}{(5)}$.

For these measurements and other data concerning the examined skulls of the hamster I refer to Table I. The letter " $n$ " indicates the number of specimens examined; under the heading "range" the minimum and the maximum values of a certain dimension or that of a certain index are given; "mean" is the arithmetic mean. I should further mention that all specimens whose measurements are indicated have the three molars full-grown. The Table means to give a general impression of the variation of the various characters in specimens of the hamster from the four different areas mentioned in that table, without giving all measurements in detail. Now in investigations like the present one three questions are important: (1) whether the variation is different in the two sexes and in the material from different areas, (2) what is the degree of variation in one sex and in a single area, and (3) what is the resultant variation of the species or subspecies. The only exact way to give a complete picture of these three problems is to use a statistical method like the one used in my previous paper on the skull of the hamster (Husson, 1953). The fact, however, that the skulls from Merseburg and from Badersleben are unsexed, and that the number of females of the hamster from Alzey is rather small, made me decide to omit a more detailed analysis of the measurements. Though hamster skulls from many other localities of central Europe have been examined (see under "Material", pp. 190-192) these data are not published here, since the number of specimens from each of these localities is too small to give an idea of the variation of the various measurements; moreover the measurements all fall into the range of those from Merseburg and Badersleben.
From Table $I$ it appears that the maximum value of the dimensions (1), (2), (3), (6), (8), (12), (13), and (16) is somewhat smaller in the skulls from the Netherlands and Belgium than in those from the three other localities, while the maximum value of the dimensions (7), (9), (10), (11), (14), and (15) in the Netherlands and Belgian specimens is equal to, or somewhat smaller or larger than that of specimens from Alzey, Merseburg and Badersleben. In my opinion these results do not allow the conclusion that the absolute size of the skull is a character separating the western hamster from the typical form. In this connection one should pay attention to the fact that half-grown individuals occur more frequently in the material from the Netherlands and Belgium than in the collections from the three other localities. This might be explained by the higher density of the human population in the Netherlands and Belgium, which undoubtedly results in a more intensive fight against these animals, resulting in reduced chances to become full-grown. Finally, there is the fact, pointed out by me in a previous paper (Husson, 1953 , p. 628), that the females are absolutely smaller than the males.

Although Table I does not seem to give much hope for finding a character which will distinguish between the hamster in the Netherlands and Belgium on one hand, and the hamster in central Germany on the other, it turns out that by suitable combination of two of them such a distinction is feasible. In the western hamster the length of the foramen incisivum is on the average greater than in the typical form, while the length of the posterior part of the palate

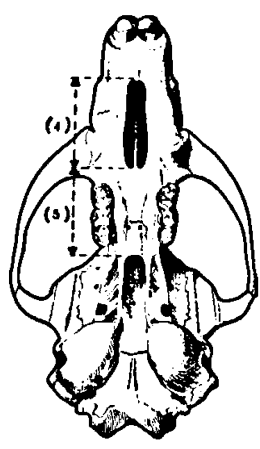

Fig. 11. Cricetus cricetus canescens Nehring. Ventral view of skull (L. $1517 \mathrm{c}$ ), indicating measurements used in the computation of the index: $\frac{100 \times(4)}{(5)},-(4)$ : length of the foramen incisivum; (5): length of the posterior part of the palate. 
(see Fig. 11) is smaller. These differences are most efficiently used when the index $\frac{100 \times \text { length for. incisivum }}{1}$ is used. Sometimes the length of the two foramina incisiva in a single specimen are not equal, so that for such a skull the minimum and the maximum values of the index are calculated. From this procedure in Table I (no. 18) two ranges and two mean values of the index result. It is interesting to note that in the skulls from the Netherlands, Belgium, and Alzey some of the males show unequal foramina incisiva, while this condition is not found in any of the females. Since the sex of the animals from Merseburg and Badersleben is unknown nothing in this respect can be said of the skulls of the hamsters from these localities.

If the value 95 of the index in question is used to separate the western hamster from the typical form, the following result is obtained: molars full-grown. In 6 juveniles from the Netherlands and Belgium in which only the first and the second molar are developed, I found the values of the index to vary from 81.1 to 87.5 , and in 4 specimens in which the third molar was not developed at the level of the second molar the index varies from 88.5 to 93.5 . In juveniles of the typical form these values also lie distinctly below those of adult specimens: in 16 juveniles from Alzey in which only the first and the second molars are developed, the values of the index vary from 67.53 to 82.5 , while the mean is 70.75 ; in 11 skulls in which the third molar is more or less developed, the index varies from 80.0 to 87.95 , the mean being 84.32. Therefore the index of the juveniles of the western hamster from the Netherlands and Belgium has on the average the same value as that of the adults from the typical form, while the juveniles of the latter form in this respect agree with

\begin{tabular}{|c|c|c|c|c|c|c|c|}
\hline & & \multicolumn{2}{|c|}{ Number } & \multicolumn{2}{|c|}{ Index $>95$} & \multicolumn{2}{|c|}{ Index $<95$} \\
\hline & & $\begin{array}{l}\text { for.inc. } \\
\text { equal }\end{array}$ & $\begin{array}{l}\text { for.inc. } \\
\text { unequal }\end{array}$ & $\begin{array}{l}\text { for.inc. } \\
\text { equal }\end{array}$ & $\begin{array}{l}\text { for.inc. } \\
\text { unequal }\end{array}$ & $\begin{array}{l}\text { for.inc. } \\
\text { equal }\end{array}$ & $\begin{array}{l}\text { for.inc. } \\
\text { unequal }\end{array}$ \\
\hline $\begin{array}{l}\text { The Netherlands }+ \\
\text { Belgium }\end{array}$ & 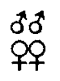 & $\begin{array}{l}24 \\
19\end{array}$ & 2 & $\begin{array}{l}23 \\
15\end{array}$ & $\underline{2}$ & $\begin{array}{l}1 \\
4\end{array}$ & $\frac{2}{-}$ \\
\hline Alzey & $\begin{array}{l}\text { do' } \\
\text { ơ }\end{array}$ & $\begin{array}{l}22 \\
11\end{array}$ & $\frac{3}{-}$ & $\overline{2}$ & $\frac{3}{-}$ & $\begin{array}{r}22 \\
9\end{array}$ & $\frac{3}{-}$ \\
\hline Merseburg & - & 37 & 7 & 1 & - & 36 & 7 \\
\hline Badersleben & - & 31 & 10 & - & 1 & 31 & 9 \\
\hline
\end{tabular}

In 14 unsexed skulls from near Brunswick the values of this index vary from 76.13 to 91.59 , while the mean is 84.71. In 9 unsexed skulls from Proskau the range of the index is from 79.41 to 92.52 , and the mean is 83.91. The index of the skulls of the hamster occurring in Russia is still lower, since in 7 specimens from the Volga region the values of the index vary from 65.6 to 83.93 , while the value of the mean of the minimum values is 76.36 , that of the mean of the maximum values 77.35. It seems interesting to apply this index to an extensive material from Russia in order to investigate if this index may shed more light on the question whether in the eastern part of the range of distribution of Cricetus cricetus one or more separate subspecies can be distinguished (see Ellerman \& Morrison-ScotT, 1951, p. 628).

Finally it should be noted that this index is only of diagnostic importance in skulls with all the three the adult hamsters from the Volga region.

In my opinion this incisive-palate index can be considered to be a character of systematical importance to separate the western hamster, Cricetus cricetus canescens Nehring, from the typical form, Cricetus cricetus cricetus (L.) from central Europe. However, far more material is needed to decide (1) the exact range of distribution of the western hamster, and (2) whether or not the values of the above-mentioned index in adult skulls from these regions gradually pass into those of the typical form, when one moves eastward. At present there is no indication of any changes in the incisive-palate index comparable to the changes in colour pattern referred to on pages 193 to 197. It will be interesting to keep track of this index in the future in order to see whether its value as occurring in the western hamster expands into the central region along with the colour pattern. 


\section{REFERENCES}

Allen, G. M., 1914: Pattern development in mammals and birds. The American Naturalist, vol. 48, no. 571, pp. 385-412, 42 figs.

Brants, A., 1827: Het geslacht der muizen door Linnaeus opgesteld, volgens de tegenwoordige toestand der wetenschap in familien, geslachten en soorten verdeeld. Berlyn, xii+190 pp., 1 pl.

DEBY, J., 1848: Histoire naturelle de la Belgique. Mammifères. Bruxelles, vol. 1, 189 pp., figs.; vol. 2, 192 pp., figs.

Didien, R. \& P. Rode, 1935: Les Mammifères de France. Paris, 398 pp., 214 figs., pls. i-xxvii, col. frontisp.

Dupond, CH., 1932: La propagation du hamster en Belgique. Bull. Mus. Hist. Nat. Belg., vol. 8, no. 26, 43 pp., 9 figs., 1 map.

Ellerman, J. R. \& T. C. S. Morrison-Scott, 1951: Checklist of Palaearctic and Indian Mammals 1758 to 1946. London, 810 pp., 1 map.

Eykman, C., 1937: De Nederlandsche zoogdieren. Deel I. Insecteneters en Knaagdieren (Insectivora et Rodentia). Rotterdam, 83 pp., 46 figs., 19 pls.

Frechкop, S., 1936: Remarque au sujet du Hamster belge. Ann. Soc. Zool. Belg., vol. 66, pp. 123-126.

Honvath, A., 1881: Einfluss verschiedener Temperaturen auf die Winterschläfer. Verh. Physik.-Medicin. Gesellsch. Würzburg, n. s., vol. 15, pp. 187-219.

Husson, A. M., 1949a: Over het voorkomen van de hamster, Cricetus cricetus (L.), in Nederland. Publicaties Natuurh. Gen. Limburg, Reeks 2, pp. 14-54, 1 fig., 3 maps (with an English summary).

Husson, A. M., 1949b : Aantekeningen over de hamster. Natuurh. Maandblad, Maastricht, vol. 38, pp. 111-115, 3 figs. (with an English summary).

Husson, A. M., 1953: On the foramen magnum occipitale and some other skull-measurements of Cricetus cricetus canescens Nehring with respect to sexual dimorphism. Proc. Kon. Ned. Akad. Wetensch. Amsterdam, ser. C, vol. 56, pp. 609-630, 6 figs., 6 tab.

Husson, A. M., 1957: Faunistische gegevens over de zoogdieren van Zuid-Limburg. Natuurh. Maandblad, Maastricht, vol. 46, pp. 61-81 (with an English summary).

Miller, G. S., 1912: Catalogue of the mammals of Western Europe (Europe exclusive of Russia) in the collection of the British Museum. London, xv+1019 pp., 123 figs., tab.

Nehring, A., 1894: Die Verbreitung des Hamsters (Cricetus vulgaris) in Deutschland. Archiv für Naturgeschichte, vol. 60 , pp. $15-32$, map iii.

Nehrivg, A., 1899: Einige Varietäten des gemeinen Ham- sters (Cricetus vulgaris Desm.). Sitz.-Ber. Gesellsch. naturf. Freunde Berlin 1899, Nr. 1, pp. 1-3.

Novikov, K. L., 1935: Systematic peculiarities of the hamster (Cricetus cricetus L.). Bull. Soc. Nat. Moscou, sect. Biol., n. s., vol. 44, pp. 302-313 (Russian with an English summary).

Petzsch, H., 1933: Einige Beobachtungen an gefangenen Hamstern (Cricetus cricetus L.). Zeitschr. für Säugetierk., vol. 8, pp. 222-227, 2 figs.

Petzsch, H., 1936: Beiträge zur Biologie, insbesondere Fortpflanzungsbiologie des Hamsters (Cricetus cricetus L.). Ergebnisse und Probleme. Zeitschr. Kleintierkunde und Pelztierkunde. "Kleintier und Pelztier", vol. 12, 83 pp., 7 figs., 1 map (= Monographien der Wildsäugetiere, vol. 1).

Petzsch, H., 1940a: Grundsätzliches über die Verwendbarkeit des Hamsters (Cricetus cricetus L.) für genetische Untersuchungen und für die Haustierforschung. Zeitschr. Tierz. und Züchtungsbiologie., vol. 47, pp. 45-51, 5 figs.

Petzsch, H., 1940b: Vererbungsuntersuchungen (I) an Farbspielen des Hamsters (Cricetus cricetus L.). Zeitschr. Tierz. und Züchtungsbiologie, vol. 48, pp. 67-83, 12 figs.

Petzsch, H., 1949: Ueber anomale Weissscheckungen bei der Hausmaus (Mus musculus) und beim Hamster (Cricetus cricetus). Mitt. Mus. Naturk. Vorgesch. und Naturw. Arb. Magdeburg, vol. 2, pp. 1-8.

Perzsch, H., 1950: Der Hamster. Die Neue Brehm-Bücherei, Leipzig, 56 pp., 26 figs.

Petzsch, H. \& H. Petzsch, 1956: Zum Problem des Vererbungsmodus für Melanismus bei dem gemeinen Hamster (Cricetus cricetus L.) in Hinsicht auf die Evolution. Der Zool. Garten, n. .s, vol. 22, pp. 119-154, 1 fig.

Sulzer, F. G., 1774: Versuch einer Naturgeschichte des Hamsters. Göttingen - Gotha, 212 pp., 5 pls. (In 1949 an annotated reprint of this work with a biography of Sulzer was edited by $\mathbf{H}$. Petzsch. Verlag Naturkunde, Hannover-Berlin, 197 pp., i-xvi pls.).

WePNER, A., 1936: Zur Frage der subspezifischen Abtrennung des Westhamsters. Zeitschr. für Säugetierk., vol. 11 , pp. $254-256$.

Werth, E., 1934: Der gegenwärtige Stand der Hamsterfrage in Deutschland. Arb. Biol. Reichsanst. Land- und Forstwirtsch., vol. 21, pp. 201-253, 635, 4 figs., 8 maps.

Wetrstein, O., 1927: Beiträge zur Säugetierkunde Europas. II. Archiv für Naturgesch., Abt. A, vol. 92, pp. 64146. 